I thank Mr J Magell and Dr C K Heffernan of Blackburn Royal Infirmary for their help.

${ }^{1}$ Erdohazi M, Newman RL. Aluminium hydroxide granuloma. $\mathrm{Br} \mathrm{Med} \mathcal{F}$ 1971 ; iii: $621-3$

2 Savage J. Aluminium hydroxide granuloma. Proc Roy Soc Med 1973;66: 984-5.

${ }^{3}$ Morgan WP, Leicester G. The role of depilation and deodorants in hidradenitis suppurativa. Arch Dermatol 1982;118:101-2.

- Lenz TR. Foreign-body granuloma caused by jet injection of tetanus toxoid. Rocky Mountain Medical fournal 1966;63:48.

${ }^{5}$ Kleinhans D, Knoth W. Granulomas of axillae (zirconium ?). Dermatologica $1976 ; 152: 161-7$

(Accepted 7 March 1984)

Department of Rheumatology, Manchester Medical School, Manchester M13 9PT

SIMON WILLIAMS, medical student

A J FREEMONT, MB, lecturer in osteoarticular pathology

Correspondence to: $\mathrm{Mr} \mathrm{S}$ Williams.

\section{Sclerotherapy for hydrocele and epididymal cysts: a five year study}

The treatment of hydroceles by injecting various agents has been used intermittently over several centuries, ${ }^{1}$ Nevertheless, surgery is now recommended as the definitive treatment. The reason injection treatment has fallen out of favour is not clear but such neglect appears to be based on poor evidence. ${ }^{2}$ The early results of a prospective study of sclerotherapy for hydrocele and epididymal cysts were presented in $1979^{3}$; this paper reviews the results five years after treatment.

\section{Patients, methods, and results}

Seventy symptomatic patients (mean age 63, range 35-86) with one or more hydrocele or epididymal cysts were included in the study (those who had an ipsilateral inguinal hernia were rejected). Some 14 patients had to be excluded as they did not complete the course of treatment; six required surgery as there was a bloodstained tap or the lump did not transilluminate; five failed to attend follow up appointments; and three died of unrelated causes. The 56 remaining patients had 49 hydroceles and 14 epididymal cysts. The method of treatment ${ }^{3}$ was, in summary, to transilluminate the scrotum to confirm the diagnosis and identify the testis. A size 18 gauge Medicut was then inserted into the upper border of the hydrocele or cyst under local anaesthesia. The Medicut was used because a plastic cannula is less likely to damage the lining of the sac and is unlikely to slip out when the operator is aspirating fluid or injecting sclerosant. The fluid was completely aspirated and its volume measured. The sclerosant $(2.5 \%$ phenol in water $)$ was then injected: $5 \mathrm{ml}$ into a sac containing less than $50 \mathrm{ml}$ of fluid, $10 \mathrm{ml}$ for $51-200 \mathrm{ml} ; 15 \mathrm{ml}$ for $201-400 \mathrm{ml}$; and $20 \mathrm{ml}$ for over $400 \mathrm{ml}$. The patients were seen every six weeks and the treatment repeated until no fluid reaccumulated.

All 49 hydroceles and 14 epididymal cysts were successfully treated (table). The commonest side effect was testicular pain at injection, which

Details of treatment

\begin{tabular}{|c|c|c|c|c|c|}
\hline $\begin{array}{l}\text { Size } \\
(\mathrm{ml})\end{array}$ & Type & No & $\begin{array}{l}\text { Mean no of } \\
\text { times injected } \\
\quad \text { (range) }\end{array}$ & $\begin{array}{l}\text { Recurrence at } \\
1 \text { year (size } \\
\text { of recurrence) }\end{array}$ & $\begin{array}{l}\text { Recurrence at } \\
5 \text { years (size } \\
\text { of recurrence) }\end{array}$ \\
\hline $0-50$ & $\begin{array}{l}\text { Epididymal cyst } \\
\text { Hydrocele }\end{array}$ & $\begin{array}{l}8 \\
4\end{array}$ & $\begin{array}{l}1 \cdot 1(1-2) \\
1 \cdot 25(1-2)\end{array}$ & $1(40 \mathrm{ml})$ & \\
\hline $51-200$ & $\begin{array}{l}\text { Epididymal cyst } \\
\text { Hydrocele }\end{array}$ & $\begin{array}{r}5 \\
18\end{array}$ & $\begin{array}{l}1.6(1-3) \\
1.7(1-3)\end{array}$ & $1(15 \mathrm{ml})$ & $1(20 \mathrm{ml})$ \\
\hline $201-400$ & $\begin{array}{l}\text { Epididymal cyst } \\
\text { Hydrocele }\end{array}$ & $\begin{array}{r}1 \\
18\end{array}$ & $\begin{array}{l}4 \\
1 \cdot 7(1-3)\end{array}$ & $1(60 \mathrm{ml})$ & $2(20 \mathrm{ml}, 100 \mathrm{ml})$ \\
\hline$\geqslant 401$ & Hydrocele & 9 & $2 \cdot 2(1-4)$ & & $1(15 \mathrm{ml})$ \\
\hline
\end{tabular}

lasted for only a short time. Eleven developed some epididymal thickening but this was noted only in the large hydroceles; three complained of testicular tenderness for up to two weeks after injection; two developed a mild infection, which resolved with antibiotics; and one patient developed a transien macular rash thought to be an allergic reaction to phenol. One year after treatment two hydroceles and one epididymal cyst had recurred and these were retreated. After five years 11 patients had died and three could not be traced, leaving 42 for assessment; these patients had had 38 hydroceles and
10 epididymal cysts. Four hydroceles recurred (table), but only one (of $100 \mathrm{ml}$ in what had originally been $270 \mathrm{ml}$ ) was noticed by the patient.

\section{Comment}

The early results of this study confirmed the efficacy of this method of treatment. ${ }^{4}$ Recently Macfarlane using a different sclerosant has reported equally good early results. ${ }^{5}$ The three early recurrences were successfully retreated and had not recurred at the five year review. Three of the patients with late recurrences were asymptomatic and did not require further treatment, leaving a symptomatic recurrence rate of $3 \%$ for hydroceles. The testicular pain after injection of the phenol is mild and may be avoided by injecting a small quantity of local anaesthetic into the sac before the phenol. None of the complications resulted in hospital admission. Residual epididymal or testicular thickening after treatment of the larger hydroceles is not surprising in view of the size of the tunica vaginalis. Nevertheless, the end result was always acceptable to the patient given the appreciable reduction in the size of the swelling. The other six complications were minor and might be regarded as unimportant compared with those of operative treatment. 4

This report refutes the criticism that recurrences are likely to occur over the long term as only one notable recurrence has appeared over five years. Although this method is simple, it must be performed properly. Thus phenol sclerotherapy is highly effective, safe, and cheap. It should always be considered for the treatment of adults and should be regarded as the treatment of choice in the elderly.

${ }^{1}$ Landes RR, Leonhardt KO. The history of hydrocele. Urologic Survey $1967 ; 17: 135-46$

${ }^{2} \mathrm{Br}$ Med F. Injecting hydroceles-an unproved treatment ? Br Med $\mathcal{F} 1973$; 3:344.

${ }^{3}$ Nash JR. Sclerotherapy for hydrocele and epididymal cysts. Br $\mathcal{F}$ Surg $1979 ; 66: 289-90$

Maloney GE. Comparison of results of treatment of hydrocele and epididymal cyst by surgery and injection. $B r \operatorname{Med} \mathcal{F} 1975 ; 3: 478-9$.

${ }^{5}$ Macfarlane JR. Sclerosant therapy for hydroceles and epididymal cysts. Br $\mathcal{F}$ Urol 1983;55:81-2.

(Accepted 23 February 1984)

Department of Surgery, Royal Infirmary, Leicester LE2 7LK

J R NASH, MD, FRCS, lecturer

\section{Reversal with balsalazide of infertility caused by sulphasalazine}

Sulphasalazine is commonly used to maintain remission in ulcerative colitis but has many toxic side effects including infertility in men. Compounds of the drug have been designed without the sulphonamide moiety, which is thought to be the specifically toxic factor. We used one of these new compounds, balsalazide (5-(carboxy ethylcarbamoyl4-phenylazo)-salicylic acid), to treat three young men who presented with infertility induced by sulphasalazine. We report here the results.

\section{Patients, methods, and results}

Three men with ulcerative colitis, in whom remission of disease was maintained with sulphasalazine 2-3 g daily, presented with infertility. Two had a history of relapse after stopping sulphasalazine and had subsequently taken the drug for nine and 12 months respectively. The third had not experimented with withdrawal of treatment and had taken sulphasalazine continually for five years. Two had fathered children before receiving sulphasalazine. After giving informed consent the patients received balsalazide $2 \mathrm{~g}$ daily for four months. They were asked to provide semen specimens before and at monthly intervals during treatment; the numbers and motility of their sperms were determined. Full blood counts, serum biochemical tests, and urine microscopy were performed monthly. Clinical examination and sigmoidoscopy were used to monitor the patients' colitis, and rectal mucosal biopsies were undertaken before and after treatment.

Remission of colitis was maintained in all three patients as judged by their symptoms and the sigmoidoscopic and histological appearances of the mucosa. The table shows that the sperm count and motility returned to normal in two patients within the treatment period. The third patient failed to provide more than the initial semen specimen despite repeated requests, but his wife became pregnant during the third month of treatment. No patient reported 